\title{
HUBUNGAN PENGETAHUAN PASIEN TIRAH BARING YANG TERLALU LAMA DENGAN KEJADIN DEKUBITUS DI RUMAH SAKIT BANGKATAN PTPN 2 BINJAI TAHUN 2017
}

\author{
The Relationship of Knowledge of The Long-Light Barring Patients With Docubitus \\ in The PTPN 2 Binjai Building Hospital in 2017
}

\author{
Wirda Faswita ${ }^{1}$ \\ ${ }^{1}$ Dosen Akademi Keperawatan Sehat Binjai \\ E-mail: wirdafaswita@gmail.com
}

\begin{abstract}
Abstrak
Manusia menjalani hampir sebagian penuh hidupnya ditempat tidur. Pada umumnya tinggal ditempat tidur tidak menimbulkan masalah justru akan timbul masalah jika manusia tidak cukup istirahat (istirahat malam). Selama tidur manusia membangun kembali energinya. Masalah akan timbul jika seseorang yang sedang menderita penyakit terlalu lama beristirahat ditempat tidur (Stevens, 2010). Berdasarkan pengalaman peneliti pada saat praktek di Rumah Sakit umum djoelham Binjai, masih ada pasien tirah baring yang mengalami dekubitus khususnya pada pasien yang sudah tirah baring terlalu lama. Hal ini dikarenakan tingginya beban perawat, sementara pasien tirah baring memiliki ketergantungan yang sangat tinggi terhadap perawat disebabkan kurangnya pengetahuan pasien tentang prosedur pergantian posisi saat berbaring di tempat tidur, dari 55 orang pasien tirah baring yang cukup lama ditemukan 30 orang di antaranya mengalami luka dekubitus. Jenis penelitian yang digunakan yaitu bersifat deskriptif dengan metode survei yang bertujuan untuk mengetahui “ Hubungan Pengetahuan Pasien Tirah Baring yang Terlalu Lama Dengan Kejadian Dekubitus Di Rumah Sakit umum djoelham Binjai Tahun 2017". Berdasarkan Tabel 5 dapat dilihat hasil penelitian yang dilakukan menunjukan bahwa mayoritas Pasien tirah baring terlalu lama yang mengalami luka Dekubitus di Rumah Sakit Bangkatan umum djoelham Binjai Tahun 2017 memiliki tingkat pengetahuan yang kurang yaitu sebanyak 20 orang (66,6\%).Hal ini membuktikan bahwa akibat kurangnya pengetahuan pasien tirah baring yang terlalu lama tentang luka dekubitus maka angka kejadian luka dekubitus pada pasien tirah baring yang terlalu lamapun akan semakin meningkat.
\end{abstract}

Kata kunci : Pengetahuan pasien tirah baring, Dekubitus.

\begin{abstract}
Humans live most of their lives in bed. In general, staying in bed does not cause problems, it will cause problems if humans do not have enough rest (night rest). During sleep, humans rebuild their energy. Problems will arise if someone who is suffering from an illness takes too long to rest in bed (Stevens, 2010). Based on the experience of researchers during the practice at the Djoelham Binjai General Hospital, there are still patients with bed rest who experience pressure sores, especially in patients who have been lying too long. This is due to the high burden of nurses, while bed rest patients have a very high dependence on nurses due to a lack of knowledge of patients about the procedure of changing positions while lying in bed, from 55 patients who had bed rest long enough to find 30 of them had pressure sores. The type of research used is descriptive with a survey method which aims to find out "The Relationship between Patients' Knowledge of Tiring Baring that Is Too Long With Decubitus Events in General Hospital Djoelham Binjai in 2017". Based on Table 5. It can be seen the results of the research conducted show that the majority of patients lying too long who experience decubitus wounds in the General Bangkat Hospital djoelham Binjai 2017 have a level of knowledge that is as much as 20 people $(66.6 \%)$.This proves that due to lack of knowledge patients who lie too long about pressure sores, the incidence of pressure sores in patients lying too late will increase.
\end{abstract}

Keywords: Knowledge of bed rest patients, Decubitus. 


\section{PENDAHULUAN}

Manusia menjalani hampir sebagian penuh hidupnya ditempat tidur. Pada umumnya tinggal ditempat tidur tidak menimbulkan masalah justru akan timbul masalah jika manusia tidak cukup istirahat (istirahat malam). Selama tidur manusia membangun kembali energinya. Masalah akan timbul jika seseorang yang sedang menderita penyakit terlalu lama beristirahat ditempat tidur (Stevens, 2010).

Pasien imobilisasi pada umumnya tidak bergerak pada malam hari karena tidak adanya gerakan pasif maupun aktif. Skor aktifitas sakral pasien pada kondisi tersebut adalah nol gerakan per jam, yang mengakibatkan tekanan pada daerah kulit yang sama secara teru-menerus. Tekanan akan memberikan pengaruh pada daerah kulit saral ketika pada posisi berbaring. Aliran darah didalam tubuh akan terhambat khususnya pada daerah kulit yang tertekan dan menghasilkan anoksia jaringan dan nekrosis (Sudoyo, 2010).

Dekubitus adalah luka yang timbul karena tekanan terutama pada bagian tulang-tulang yang menonjol akibat tirah baring yang terlalu lama di tempat tidur. Kasus dekubitus dapat terjadi pada semua umur terutama pada lanjut usia dengan frekuensi kejadiannya sama pada peria dan wanita (Siregar, 2010).

Dekubitus juga beresiko tinggi pada orang-orang yang tidak mampu merasakan nyeri, karena nyeri adalah tanda yang secara normal mendorong seseorang untuk bergerak. Kerusakan saraf (cedera, stroke, diabetes dan koma). Diabetes millitus adalah suatu penyakit kronis yang disebabkan oleh berkurangnya produksi insulin oleh pankreas, bail yang diturunkan maupun yang didapat atau oleh ketidak efektifan produksi insulin. Kekurangan ini meningkatkan konsentrasi glukosa dalam darah, dimana ini dapat membahayakan sistem tubuh khususnya pembuluh darah dan sistem syaraf sehingga menyebabkan berkurangnya kemampuan untuk merasakan nyeri sehingga menjadi salah satu resiko terjadinya dekubitus ( WHO, 2009).

Kejadian dekubitus di Amerika masih cukup tinggi dan perlu mendapatkan perhatian dari kalangan tenaga kesehatan.
Hasil penelitian menunjukan bahwa insiden terjadinya dekubitus bervariasi, tetapi secara umum dilaporkan bahwa 6-12\% terjadi ditatanan perawatan acute care, 15$25 \%$ ditatanan perawatan jangka panjang dan $8-16 \%$ ditatanan perawatan ruamah (Murrty, 2010).

Pada oktober 2012 di RSUD Dr. Moewardi Surakarta tercatat dari 160 pasien tirah baring 82 orang pasiennya mengalami dekubitus, pada tahun 2013 pasien tirah baring yang mengalami dekubitus sebanyak 62 orang dari 120 pasien.

Purwaningsih pada tahun 2006 melakukan penelitian pada pasien tirah baring menyatakan bahwa dari 80 orang pasien tirah baring yang dirawat di RSUD Dr. Wahidin Sudirohusodo Makasar sebanyak 15,8\% mengalami luka dekubitus. Stiyajati pada tahun 2014 juga melakukan penelitian yang hampir sama pada pasien tirah baring di Dirumah Sakit Moewardi Surakarta, dimana kejadian luka dekubitus sebanyak $38,2 \%$. Dari penelitian tersebut dapat diasumsikan bahwa kualitas pelayanan keperawatan yang diberikan di Rumah Sakit dapat dikatakan belum baik dan perawatan belum menempatkan pencegahan dekubitus menjadi prioritas yang tinggi dalam pelayanan keperawatan. Dekubitus merupakan problem yang serius karena dapat mengakibatkan meningktnya, biaya, lama perawatan dirumah sakit serta memperlambat program rehabilitasi bagi penderita (Setiyawan, 2011).

Tindakan pencegahan dapat dilakukan dengan melakukan massase pada kulit pasien, pemeliharaan keadaan umum pada penderita, ataupun dengan melakukan tindakan khusus seperti mengurangi tekanan luar yang berlebih pada daerah tertentu dengan cara perubahan posisi tubuh tiap 2 jam sekali selama 24 jam ditempat tidur. Pencegahan dekubitus juga dapat dilakukan dengan peningkatan pengetahuan pasien tirah baring itu sendiri atau pun pengetahuan keluarga. Tentang bagaimana cara pencegahan terjadinya dekubitus.

Berdasarkan pengalaman peneliti pada saat praktek di Rumah Sakit Bangkatan PTPN 2 Binjai, masih ada 
pasien tirah baring yang mengalami dekubitus khususnya pada pasien yang sudah tirah baring terlalu lama. Hal ini dikarenakan tingginya beban perawat, sementara pasien tirah baring memiliki ketergantungan yang sangat tinggi terhadap perawat disebabkan kurangnya pengetahuan pasien tentang prosedur pergantian posisi saat berbaring di tempat tidur, dari 55 orang pasien tirah baring yang cukup lama ditemukan 30 orang di antaranya mengalami luka dekubitus. Oleh karena itu, peneliti tertarik untuk melekukan penelitian dengan judul "Hubungan Pengetahuan Pasien Tirah Baring Yang Terlalu Lama Dengan Kejadin Dekubitus Di Rumah Sakit Bangkatan PTPN II Binjai Tahun 2017”.
METODE

Jenis penelitian yang digunakan yaitu Deskriptif korelasional dengan pendekatan Cross sectional. Desain Penelitian yang digunakan adalah Deskriptif dengan metode survei.

Lokasi yang dipilih menjadi tempat penelitian adalah Rumah Sakit

PTPN II Bangkatan Binjai.

Penelitian ini dilakukan mulai bulan September 2017 sampai dengan Desember 2017. Populasi dalam penelitian ini adalah semua Pasien tirah baring yang sudah terlalu lama di Rumah Sakit PTPN II Bangkatan Binjai mulai dari bulan September 2017 yaitu sebanyak 30 orang. Sampel dalam penelitian sebanyak 30 orang di pilih dengan menggunakan Random sampling

HASIL PENELITIAN

Tabel 1. Distribusi Frekuensi Pasien Tirah Baring Terlalu Lama Berdasarkan Kejadian Dekubitus, Usia, Jenis Kelamin dan Pendidikan di Rumah Sakit Bangkatan PTPN 2 Binjai Tahun 2017.

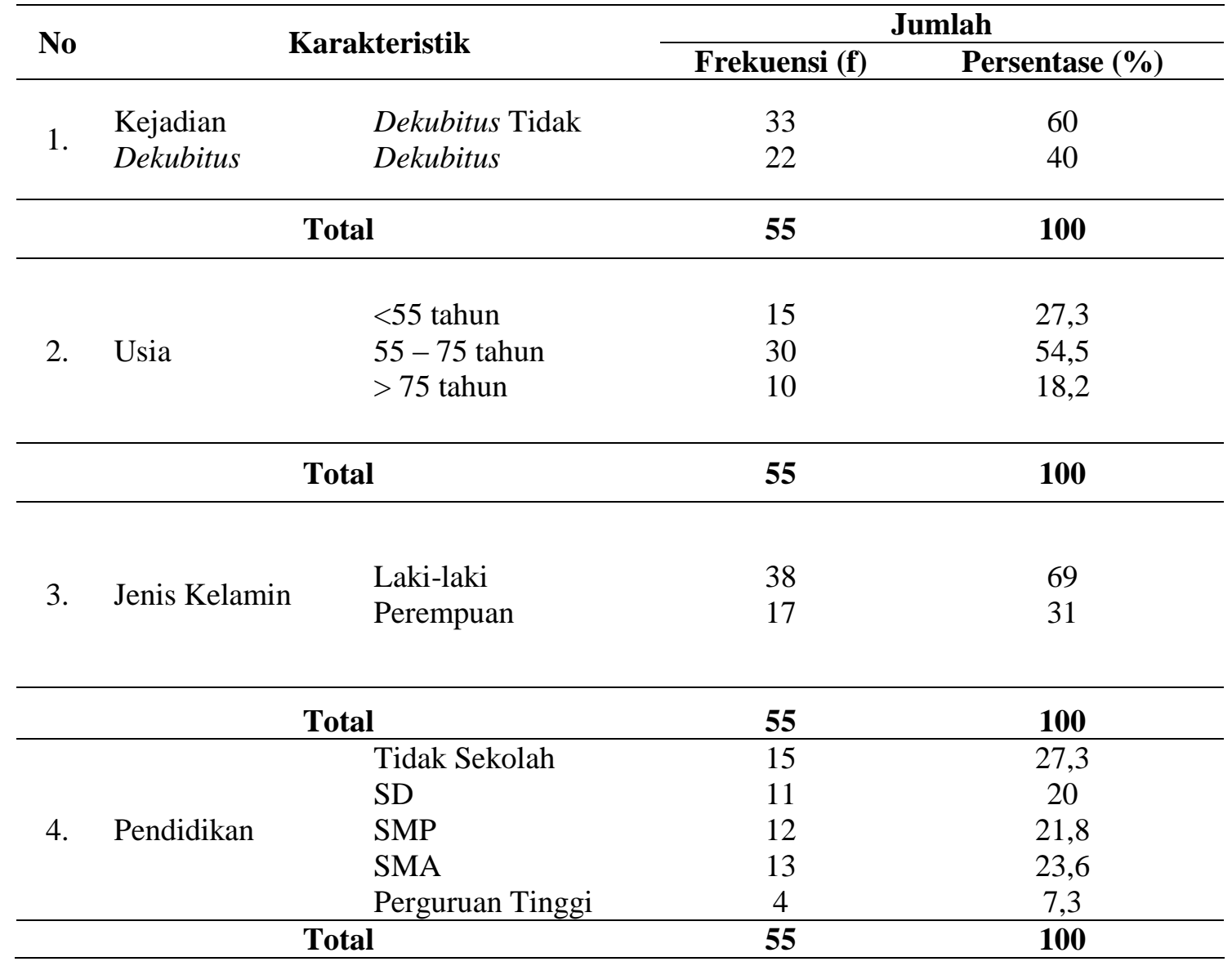


Berdasarkan Tabel 1 hasil penelitian yang dilakukan menunjukkan pasien tirah baring yang mengalami kejadian Dekubitus di Rumah Sakit Bangkatan PTPN 2 Binjai yaitu sebanyak 33 orang (60\%) dan yang tidak mengalami kejadian Dekubitus adalah sebanyak 22 orang (40\%). Hasil penelitian yang dilakukan menunjukkan mayoritas usia pasien tirah baring yang terlalu lama $55-75$ tahun yaitu sebanyak 30 orang $(54,5)$ dan minoritas pasien tirah baring yang terlalu lam $>75$ tahun sebanyak 10 orang $(18,2 \%)$. Hasil penelitian yang dilakukan menunjukkan mayoritas pasien tirah baring yang terlalu lam berjenis kelamin laki-laki yaitu sebanyak 38 orang (69\%) dan minoritas terdapat pada jenis kelamin perempuan yaitu sebanyak 17 orang (31\%). Hasil penelitian yang dilakukan menunjukkan mayoritas pasien tirah baring yang terlalu lama memiliki tingkat pendidikan tidak sekolah yaitu sebanyak 15 orang $(27,3 \%)$ dan minoritas terdapat pada tingkat pendidikan perguruan tinggi yaitu sebanyak 4 orang $(7,3 \%)$.

Tabel 2. Hubungan Penegetahuan Pasien Tirah Baring Yang Terlalu Lama Dengan Kejadin Dekubitus Berdasarkan Usia Di Rumah Sakit Bangkatan PTPN 2 Binjai Tahun 2017.

\begin{tabular}{|c|c|c|c|c|c|c|c|c|}
\hline \multirow{3}{*}{ No. } & \multirow{3}{*}{ Usia } & \multicolumn{6}{|c|}{ Kejadian Dekubitus } & \multirow{3}{*}{$P$ Value } \\
\hline & & \multicolumn{2}{|c|}{ Dekubitus } & \multicolumn{2}{|c|}{$\begin{array}{c}\text { Tidak } \\
\text { Dekubitus }\end{array}$} & \multicolumn{2}{|c|}{ Jumlah } & \\
\hline & & $\mathbf{F}$ & $\%$ & $\mathbf{F}$ & $\%$ & $\mathbf{F}$ & $\%$ & \\
\hline 1. & $<55$ & 5 & 33,3 & 10 & 66,7 & 15 & 100 & \multirow{3}{*}{0.02} \\
\hline 2. & $55-75$ & 20 & 66,6 & 10 & 33,4 & 30 & 100 & \\
\hline 3. & $>75$ & 5 & 50 & 5 & 50 & 10 & 100 & \\
\hline
\end{tabular}

Berdasarkan Tabel 2 di atas dapat disimpulkan bahwa mayoritas Pasien tirah baring terlalu lama yang mengalami luka Dekubitus di Rumah Sakit Bangkatan PTPN 2 Binjai Tahun 2017 terdapat pada usia 55-75 tahun yaitu sebanyak 20 orang $(66.6 \%)$ dan minoritas terdapat pada usia $>55$ tahun yaitu sebanyak 5 orang (33\%). Hasil uji chi square menunjukan nilai $p<0,05$ yang berarti ada hubungan yang signifikan antara usia dengan kejadian dekubitus

Tabel 3. Hubungan Penegetahuan Pasien Tirah Baring Yang Terlalu Lama Dengan Kejadin Dekubitus Berdasarkan Jenis Kelamin Di Rumah Sakit Bangkatan PTPN 2 Binjai Tahun 2017.

\begin{tabular}{|c|c|c|c|c|c|c|c|c|}
\hline \multirow{3}{*}{ No. } & \multicolumn{7}{|c|}{ Kejadian Dekubitus } & \multirow[b]{2}{*}{$P$ Value } \\
\hline & \multirow{2}{*}{ Jenis Kelamin } & \multicolumn{2}{|c|}{ Dekubitus } & \multicolumn{2}{|c|}{$\begin{array}{c}\text { Tidak } \\
\text { Dekubitus }\end{array}$} & \multicolumn{2}{|c|}{ Jumlah } & \\
\hline & & $\mathbf{f}$ & $\%$ & $\mathbf{F}$ & $\%$ & $\mathbf{F}$ & $\%$ & \\
\hline 1. & Laki-laki & 22 & 57,8 & 16 & 42,2 & 38 & 100 & 0.03 \\
\hline 2. & Perempuan & 8 & 47 & 9 & 53 & 17 & 100 & \\
\hline
\end{tabular}

Berdasarkan Tabel 3 di atas dapat disimpulkan bahwa mayoritas pasien tirah baring terlalu lama yang mengalami Dekubitus di Rumah Sakit Bangkatan PTPN 2 Binjai Tahun 201 terdapat pada jenis kelamin laki-laki yaitu sebanyak 22 orang
$(57,8 \%)$ dan minoritas terdapat pada jenis kelamin perempuan yaitu sebanyak 8 orang (47\%). Hasil uji chi square menunjukan nilai $p<0,05$ yang berarti ada pengaruh yang signifikan antara jenis kelamindengan kejadian Dekubitus. 
Tabel 4. Hubungan Penegetahuan Pasien Tirah Baring Yang Terlalu Lama Dengan Kejadin Dekubitus Berdasarkan Pendidikan Di Rumah Sakit Bangkatan PTPN 2 Binjai Tahun 2017.

\begin{tabular}{|c|c|c|c|c|c|c|c|c|}
\hline \multirow{3}{*}{ No. } & \multirow{3}{*}{ Pendidikan } & \multicolumn{6}{|c|}{ Kejadian Dekubitus } & \multirow{3}{*}{$P$ Value } \\
\hline & & \multicolumn{2}{|c|}{ Dekubitus } & \multicolumn{2}{|c|}{$\begin{array}{c}\text { Tidak } \\
\text { Dekubitus }\end{array}$} & \multicolumn{2}{|c|}{ Jumlah } & \\
\hline & & $\mathbf{F}$ & $\%$ & f & $\%$ & $\mathbf{F}$ & $\%$ & \\
\hline 1. & $\begin{array}{l}\text { Tidak } \\
\text { Sekolah }\end{array}$ & 10 & 66.6 & 5 & 33,4 & 15 & 100 & \\
\hline 2. & SD & 4 & 36,3 & 7 & 63,7 & 11 & 100 & \\
\hline 3. & SMP & 7 & 58,3 & 5 & 41,7 & 12 & 100 & 0.03 \\
\hline 4. & SMA & 8 & 61,6 & 5 & 38,4 & 13 & 100 & \\
\hline 5. & $\begin{array}{l}\text { Perguruan } \\
\text { Tinggi }\end{array}$ & 1 & 25 & 3 & 75 & 4 & 100 & \\
\hline
\end{tabular}

Berdasarkan Tabel 4 di atas dapat disimpulkan bahwa mayoritas pasien tirah baring terlalu lama mengalami Dekubitus di Rumah Sakit Bangkatan PTPN 2 Binjai Tahun 2017 terdapat pada tingkat pendidikan tidak sekolah yaitu sebanyak 10 orang $(66,6 \%)$ dan minoritas terdapat pada tingkat pendidikan perguruan tinggi yaitu sebanyak 1 orang $(25 \%)$.

Hasil uji chi square menunjukan nilai $p<0,05$ yang berarti ada pengaruh yang signifikan antara tingkat pendidikan dengan kejadian Dekubitus.

Tabel 5. Hubungan Penegetahuan Pasien Tirah Baring Yang Terlalu Lama Dengan Kejadin Dekubitus Berdasarkan Tingkat Pengetahuan Di Rumah Sakit Bangkatan PTPN 2 Binjai Tahun 2017.

\begin{tabular}{|c|c|c|c|c|c|c|c|c|}
\hline \multirow{3}{*}{ No. } & \multirow{3}{*}{$\begin{array}{l}\text { Tingkat } \\
\text { Pengetahuan }\end{array}$} & \multicolumn{6}{|c|}{ Kejadian Dekubitus } & \multirow{3}{*}{$P$ Value } \\
\hline & & \multicolumn{2}{|c|}{ Dekubitus } & \multicolumn{2}{|c|}{$\begin{array}{c}\text { Tidak } \\
\text { Dekubitus }\end{array}$} & \multicolumn{2}{|c|}{ Jumlah } & \\
\hline & & $\mathbf{F}$ & $\%$ & $\mathbf{F}$ & $\%$ & $\mathbf{F}$ & $\%$ & \\
\hline 1. & Baik & 5 & 50 & 5 & 50 & 10 & 100 & \multirow{3}{*}{0.01} \\
\hline 2. & Cukup & 5 & 33,3 & 10 & 66,7 & 15 & 100 & \\
\hline 3. & Kurang & 20 & 66,6 & 10 & 33,4 & 30 & 100 & \\
\hline
\end{tabular}

Berdasarkan Tabel 5 di atas dapat disimpulkan bahwa mayoritas Pasien tirah baring terlalu lama yang mengalami luka Dekubitus di Rumah Sakit Bangkatan PTPN 2 Binjai Tahun 2017 memiliki tingkat pengetahuan yang kurang yaitu sebanyak 20 orang $(66,6 \%)$ dan minoritas terdapat pada pasien yang memiliki tingkat pengetahuan cukup yaitu sebanyak 5 orang $(33,3 \%)$. Hasil uji chi square menunjukan nilai $p<0,05$ yang berarti ada hubungan yang signifikan antara Tingkat pengetahuan pasien dengan kejadian dekubitus. 


\section{PEMBAHASAN}

Dilihat karakteristik responden berdasarkan usia bahwa dari 30 orang (100\%) responden, mayoritas pasien tirah baring yang terlalu lama terdapat pada usia 55-75 tahun yaitu sebanyak 20 orang $(66.6 \%)$. Hal ini di jelaskan bahwa usia sangat berdampak terhadap terjadinya luka dekubitus pada pasien tirah baring yang terlalu lama, karena semakin tua usia seseorang maka sistem imun dan kekebalan tubuhnya juga akan semakin menurun. Menurut notoatmojo (2011) usia adalah variabel yang selalu diperhatikan dalam penyelidikanpenyelidikan etiologi, angka-angka kesakitan dan kematian.

Kemudian berdasarkan tabel 3 dapat hasil penelitian menunjukkan bahwa mayoritas pasien tirah baring yang terlalu lama berjenis kelamin lakilaki yaitu sebanyak 22 orang $(57,8 \%)$. Hal ini dapat dijelaskan bahwa kemungkinan laki-laki untuk mengalami luka dekubitus lebih besar daripada perempuan.

Untuk tabel 4 menunjukkan bahwa mayoritas pasien tirah baring yang terlalu lama memiliki tingkat pendidikan tidak sekolah yaitu sebanyak 15 orang $(27,3 \%)$. Hal ini dapat dijelaskan bahwa pendidikan memiliki hubungan yang signifikan terhadap tingkat pengetahuan seseorang dalam mencapai tingkat kesehatan terutama menyangkut masalah kejadian lika dekubitus pada pasien tirah baring yang terlalu lama.

Seperti yang telah diungkapkan oleh Hidayat (2010). pendidikan merupakan penuntut manusia untuk berbuat dalam mengisi kehidupannya dan dapat digunakan dalam kesehariannya, sebagaimana umumnya semakin tinggi pendidikan seseorang maka akan semakin mudah untuk menerima informasi dan akan semakin baik pula pengetahuan yang dimilikinya. Dan yang terakhir pada tabel 5. dari hasil penelitian yang dilakukan menunjukan bahwa mayoritas Pasien tirah baring terlalu lama yang mengalami luka Dekubitus di Rumah Sakit Bangkatan PTPN 2 Bangkatan Binjai Tahun 2017 memiliki tingkat pengetahuan yang kurang yaitu sebanyak 20 orang $(66,6 \%)$ minoritas terdapat pada pasien yang memiliki tingkat pengetahuan cukup yaitu sebanyak 5 orang $(33,3 \%)$. Hal ini membuktikan bahwa akibat kurangnya pengetahuan pasien tirah baring yang terlalu lama tentang luka dekubitus maka angka kejadian luka dekubitus pada pasien tirah baring yang terlalu lamapun akan semakin meningkat. Oleh sebab itu, karena adanya hubungan antara tingkat pengetahuan pasien tirah baring yang terlalu lama dengan kejadian dekubitus perlu dilakukan peningkatan pengetahuan pada pasien khususnya tentang luka dekubitus yang akan terjadi pada pasien tirah baring yang terlalu lama.

\section{KESIMPULAN}

Setelah dilakukannya penelitian dengan judul hubungan tingkat pengetahuan pasien tirah baring yang terlalu lama dengan kejadian dekubitus di Rumah Sakit PTPN 2 Bangkatan Binjai Tahun 2017 maka dapat ditarik kesimpulan sebagai berikut :

Dilihat dari karakteristik yang dimiliki oleh responden berdasarkan usia bahwa dari 30 orang (100\%) responden, mayoritas pasien tirah baring yang terlalu lama terdapat pada usia 5575 tahun yaitu sebanyak 20 orang (66.6\%). Hal ini di jelaskan bahwa usia sangat berdampak terhadap terjadinya luka dekubitus pada pasien tirah baring yang terlalu lama, karena semakin tua usia seseorang maka sistem imun dan kekebalan tubuhnya juga akan semakin menurun. Menurut notoadmojo (2011) usia adalah variabel yang selalu diperhatikan dalam penyelidikanpenyelidikan etiologi, angka-angka kesakitan dan kematian.

Bila dilihat dari jenis kelamin hasil penelitian yang dilakukan menunjukkan bahwa mayoritas pasien 
tirah baring yang terlalu lama berjenis kelamin laki-laki yaitu sebanyak 22 orang $(57,8 \%)$. Hal ini dapat dijelaskan bahwa kemungkinan laki-laki untuk mengalami luka dekubitus lebih besar daripada perempuan.

Berdasarkan tingkat pendidikan yang dimiliki oleh responden dapat dilihat hasil penelitian yang dilakukan menunjukkan bahwa mayoritas pasien tirah baring yang terlalu lama memiliki tingkat pendidikan tidak sekolah yaitu sebanyak 15 orang $(27,3 \%)$. Hal ini dapat dijelaskan bahwa pendidikan memiliki hubungan yang signifikan terhadap tingkat pengetahuan seseorang dalam mencapai tingkat kesehatan terutama menyangkut masalah kejadian lika dekubitus pada pasien tirah baring yang terlalu lama.

Seperti yang telah diungkapkan oleh hidayat (2010). pendidikan merupakan penuntut manusia untuk berbuat dalam mengisi kehidupannya dan dapat digunakan dalam kesehariannya, sebagaimana umumnya semakin tinggi pendidikan seseorang maka akan semakin mudah untuk menerima informasi dan akan semakin baik pula pengetahuan yang dimilikinya. Jika dilihat dari tingkat pengetahuan yang dimiliki oleh responden dapat dilihat hasil penelitian yang dilakukan menunjukan bahwa mayoritas Pasien tirah baring terlalu lama yang mengalami luka Dekubitus di Rumah Sakit Bangkatan PTPN 2 Bangkatan Binjai Tahun 2017 memiliki tingkat pengetahuan yang kurang sebanyak 20 orang $(66,6 \%)$ minoritas terdapat pada pasien yang memiliki tingkat pengetahuan cukup yaitu sebanyak 5 orang $(33,3 \%)$. Hal ini membuktikan bahwa akibat kurangnya pengetahuan pasien tirah baring yang terlalu lama tentang luka dekubitus maka angka kejadian luka dekubitus pada pasien tirah baring yang terlalu lamapun akan semakin meningkat. Oleh sebab itu, karena adanya hubungan antara tingkat pengetahuan pasien tirah baring yang terlalu lama dengan kejadian dekubitus perlu dilakukan peningkatan pengetahuan pada pasien khususnya tentang luka dekubitus yang akan terjadi pada pasien tirah baring yang terlalu lama.

\section{SARAN}

Sejalan dengan penelitian yang telah dilakukan dan telah dijelaskan, maka penulis ingin memberikan saran untuk beberapa pihak, adapun saran yang dapat diberikan penulis adalah sebagai berikut :

1. Disarankan kepada pengambil kebijakan di Rumah Sakit Bangkatan PTPN 2 Binjai agar lebih meningkatkan pelayanan dalam memberikan penyuluhan dan penanganan yang berkualitas dalam menangani kasus dekubitus pada pasien tirah baring yang terlalu lama.

2. Diharapkan kepada para pasien tirah baring yang sudah terlalu lama agar lebih aktif untuk mendengarkan informasi yang di sampaikan oleh orang-orang sekitar baik itu keluarga maupun tenaga kesehatan yang ada tentang luka dekubitus yang dapat terjadi.

3. Bagi Institusi Akademi Keperawatan Sehat Binjai

Semoga penelitian ini dapat digunakan sebagai tambahan informasi di bidang kesehatan serta sebagai masukan bagi para mahasiswa Akademi Keperawatan Sehat Binjai.

\section{DAFTAR PUSTAKA}

Agustina, H. 2009. Perawatan Luka Modern. jurnal keperawatan unpad, 2-3.

Aisah, S. J. 2008. Pengaruh Edukasi Kelompok Sebaya Terhadap Perubahan perilaku Pencegahan Anemia Gizi Besi Pada Wanita Usia Subur Di Kota Semarang. Jurnal Keperawatan, Vol.2 No.1 : 3544. 
Arisanty, I. P. 2013. Konsep dasar manajemen perawatan luka. Jakarta: EGC.

Baranoski, S., \& Ayello, E. A. 2008. Wound Care Essential: Wound treament option (3th ed). Philadelphia: Lippincott. Williams \& Wilkins.

Broussard, K. C., \& Powers, J. G. 2013. Wound Dressings: Selecting the Most Appropriate Type. Vanderbilt Division of Dermatology, 451-456.
Casey, G. 2012. Modern Advances

in Wound Care. Kai Tiaki Nursing New Zealand, Vol.18: 23-24.

Dahlan, M. 2011. Statistik Untuk kedokteran dan Kesehatan. Jakarta: Salemba Medika.

Firman, G. 2009. Wagner and the University of Texas Wound Classification Systems of Diabetic Foot Ulcer. Medical Criteria, 1-2.

Gurning, Y. Darwin, K, Misrawati. 2013. Hubungan Tingkat Pengetahuan dan Sikap Petugas Kesehatan IGD Terhadap Tindakan Triage Berdasarkan Prioritas. Jurnal Keperawatan, 19 